\title{
Renal tumors: evaluation of prognostic factors in 98 cases from a reference hospital in Porto Alegre, Brazil
}

\author{
Tumores renais: avaliação de fatores prognósticos de 98 \\ casos em hospital de referência de Porto Alegre, Brasil
}

Alexandra Medeiros Souza de Freitas'; Antonio A. Hartmann²; Tiarajú A. de Freitas ${ }^{3}$

\begin{abstract}
Introduction: Renal cell carcinoma (RCC) is an aggressive disease worldwide. Objective: Study traditional prognostic factors associated with pathological reports and the novel markers survivin and B7-H1 by immunohistochemistry. Methods: In a reference hospital of Porto Alegre, Brazil, we conducted a cross-sectional study of RCC in patients who underwent radical nephrectomy between 2006 and 2009. We selected those who were diagnosed with the most common histologic subtypes: clear cell and papillary RCC. We retrospectively reviewed pathological data to determine traditional prognostic factors, like size, presence of coagulative necrosis, Fuhrman grade and tumor-nodemetastasis (TNM) system. Besides, we performed an immunohistochemistry (IHC) study with survivin and B7-H1. Results: Our sample had 98 cases, $90 \%$ of the cases were composed by clear cell histologic subtype, $73 \%$ were tumors classified as T1 and T2 in the TNM system, most were Fuhrman nuclear grade 2 or 3, and 70\% were positive for necrosis. In relation to the new prognostic markers, we found 50 cases positive to survivin and 38 to B7-H1. In this investigation of traditional prognostic markers and new markers we observed that only necrosis was associated with positive results of biomarkers $(p<0.001)$. Conclusion: This finding confirms previous studies that necrosis is an important factor to consider in the prognosis of RCC.
\end{abstract}

Key words: renal carcinoma; tumor markers; B7-H1; survivin; immunohistochemistry, prognostic factors.

\section{INTRODUCTION}

In 2013, in the United States (USA), more than 60,000 new cases of renal cell carcinoma (RCC) were estimated, with approximately 13,000 deaths $^{(22)}$. RCC is the seventh most common malignant disease in men, and the ninth in women ${ }^{(26)}$. Considering that a marked difference exists in prognosis and biological behavior associated to the different RCC histologic subtypes, an accurate diagnosis is essential ${ }^{(13)}$. The most common histologic types are the clear cell and the papillary RCC, accounting for $70 \%-75 \%$ and $15 \%-20 \%$ of the cases, respectively. The former presents a more aggressive behavior and is the responsible for the largest number of deaths ${ }^{(17)}$. Nowadays, due to advances in image diagnosis, $50 \%$ of the diagnosed RCC are detected accidentally ${ }^{(4)}$. Even so, RCC incidence and mortality have been increasing in recent times. This is probably explained by the fact that almost $30 \%$ of RCC present disseminated disease at diagnosis, and around $50 \%$ of them will result in death by metastasis within five years after diagnosis. Disease progression causes important alterations in mortality, with declining survival

First submission on 25/05/13; last submission on 27/09/13; accepted for publication on 27/09/13; published on 20/02/14

1. Master's degree and doctorate in Pathology from Universidade Federal de Ciências da Saúde de Porto Alegre (UFCSPA); professor at Universidade Federal do Rio Grande (FURG).

2. Doctorate in Pathology from Ludwig Maximilian Universität München (1981), with equivalence awarded by Universidade de São Paulo (USP); advisor of the Post-Graduation Program in Pathology at UFCSPA.

3. Doctorate in Economics from Universidade Federal do Rio Grande do Sul (UFRGS); professor at FURG. 
rates ranging from $60 \%$ to lower than $10 \%{ }^{(24)}$. This seems to be associated with advanced disease at diagnosis or with those who will present progression even after surgical treatment. For such cases, neither chemotherapy nor radiotherapy proved effective. There are, yet, reports that almost 20\% of RCC are responsive to some type of immunotherapy ${ }^{(3)}$. It is known that RCCs are affected by the host immune response, which may modify cancer progression ${ }^{(14)}$. Thus, the study of new prognostic markers is important for the comprehension of RCC behavior, and may improve the selection of more aggressive cases that could benefit from a more specific therapeutic options, like target cells.

Survivin and B7-H1 are new markers and have been considered promising prognostic markers ${ }^{(8-10)}$. Survivin is a bifunctional inhibitor of apoptosis protein (IAP) that has been implicated in the regulation of the cellular cycle and in the suppression of apoptosis ${ }^{(1-22)}$. It seems to be involved in resistance to radiotherapy, as well as to chemotherapy, in several human tumors. Besides, it is not detected in normal adult human tissues, but its expression has been demonstrated in several human malignant tumors, like those of kidney, breast, colon, ovary, skin, lung, lymphoma, leukemias and melanomas, becoming a probable candidate to therapeutic target in specific treatments against cancer ${ }^{(2-18-26)}$.

B7-H1 (PD-L1) is a cellular glycoprotein, of family B7, which participates in the regulation of human cell immunity and is generally restricted to macrophages ${ }^{(34)}$. This marker expression in RCC has been associated with poor prognosis ${ }^{(11)}$. Based on that, the combined expression of $\mathrm{B} 7-\mathrm{H} 1$ and survivin in RCC was studied and discovered to be associated with higher risk of cancer progression and death ${ }^{(7)}$. So, it was decided to study the immunohistochemical expression of these markers in a sample of RCC in Brazil, as well as their associations with traditional prognostic markers.

\section{OBJECTIVES}

Studying the expression of the new markers survivin and B7-H1 by IHC in RCC, and traditional prognostic factors, as well as their correlations. Due to the scarcity of data on RCC in our country, we intend to help increase knowledge upon the subject.

\section{MATERIAL AND METHODS}

After approval by the ethics committee of Universidade Federal de Ciências da Saúde de Porto Alegre (UFCSPA) (report 495/09), a sample was selected. Inclusion criteria were: patients submitted to total nephrectomy due to RCC, subtype clear cell or papillary, during 2006-2009, at Hospital Santa Casa de Porto Alegre, and who had paraffin blocks for IHC study. A review of cases was carried out by the pathologist, using the World Health Organization (WHO) classification. The following data on RCCs were analyzed: size, histological subtype, necrosis, sarcomatoid dedifferentiation, lymphocytic infiltrate, lymph node and adrenal involvement. For the evaluation of tumor extension, invasions of ureter, hilar vessels, renal pelvis, renal capsule, renal pelvis, renal capsule, renal sinus, and perirenal adipose tissue were reviewed. For the IHC study, paraffin-embedded tumor samples were randomly chosen. Blocks were sectioned at $3 \mu \mathrm{m}$, deparaffinized and rehydrated. The method Advance ${ }^{\mathrm{TM}} \mathrm{HRP}$, of Dako, was used for the detection of proteins CD 274 (B7-H1, PD-L1) and survivin. Antigen retrieval was performed using Tris-EDTA $\left(\mathrm{pH}\right.$ 9) in a water bath $\left(95^{\circ} \mathrm{C}-98^{\circ} \mathrm{C}\right)$ for 30 minutes. The endogenous peroxidase activity was blocked in two 10-minute baths in 5\% hydrogen peroxide $\left(\mathrm{H}_{2} \mathrm{O}_{2}\right) 30$ volumes, in methanol. Nonspecific reactions were blocked with Molico milk at 5\%, for one hour. Primary antibody incubation was performed overnight at $4^{\circ} \mathrm{C}$. Incubation with secondary and tertiary antibodies was performed for 40 minutes at room temperature. For the negative control of the technique, the same tissues with the same antibodies were used, except the primary, which was replaced by bovine serum albumin (BSA $1 \%)$. The antigen-antibody binding was visualized with the chromogen diaminobenzidin (DAB). Counterstaining was carried out with Harris's hematoxylin; slides were dehydrated and mounted with synthetic resin. The antibodies used were: Survivin Rabbit Polyclonal, Lab. Thermo Scientific (Fremont, USA) at dilution 1:50, and CD274 (B7-H1) Lab. Biolegend (San Diego, USA), Clone 29E.2AE at dilution 1:75. Prostatic carcinoma and palatine tonsil were used as positive controls.

For survivin, analysis of results was semiquantitative. The nuclear staining (Figure 1), quantified as the number of positive tumor cells by five high-powered fields, using a microscope Olympus CX 41 (Olympus, Japan), was considered positive. For analysis of $\mathrm{B} 7-\mathrm{H1}$, the staining of the cell membrane (Figure 2) was considered positive, with cut-off value of $10 \%$. According to the results, groups were formed: group 1 - positive cases for both markers; group 2 - positive cases for one marker and negative for the other; group 3 - negative cases for both markers. Then, associations between the groups formed at IHC and the studied anatomopathological data were analyzed. To this end, the statistical softwares Sphinx and BioEstat 5.0 were used, along with the chi-square test. 


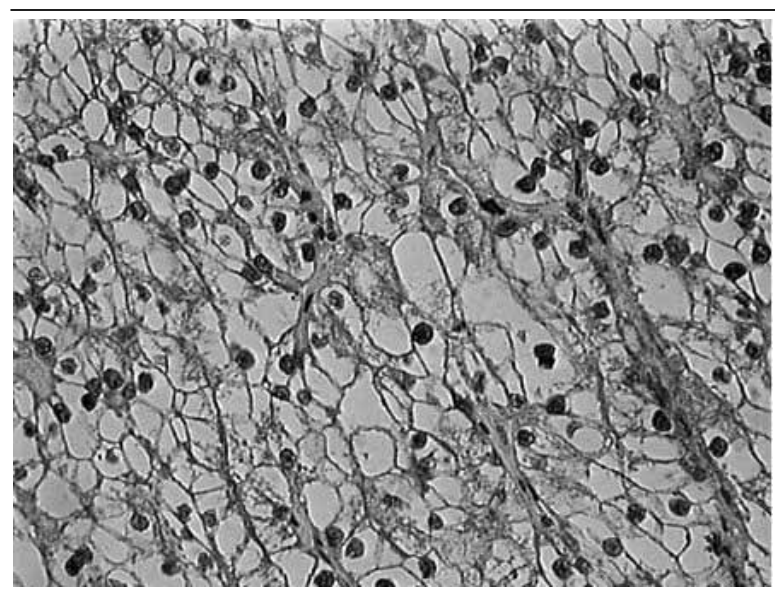

FIGURE 1 - Clear cell renal cell carcinoma positive to survivin by immunobistochemistry $40 \times$

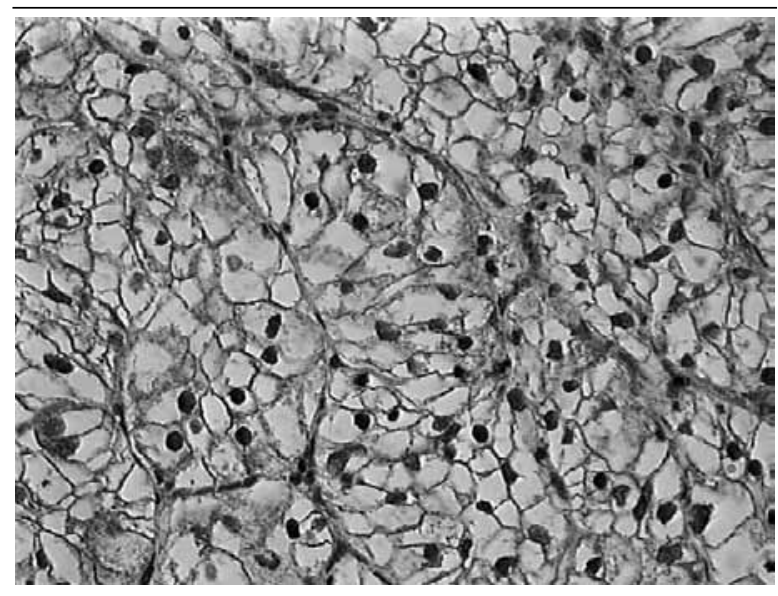

FIGURE 2 - Clear cell renal cell carcinoma positive to B7-H1 by immunobistochemistry $40 \times$

\section{RESLTS}

The total number of sample cases was 98 , with $73 \%$ being tumors classified as T1 and T2. Most of the cases (90\%) belonged to the clear cell histological subtype, and $10 \%$ to the papillary. As to Fuhrman nuclear grade, 93\% presented nuclear grades 2 and 3. In the study of tumor extension, invasion of renal capsule was found in around $50 \%$, of renal sinus in $20 \%$, of renal pelvis in $30 \%$ and of vessels in approximately $8 \%$. Invasion of the perirenal adipose tissue was positive in 30\% of the cases, while ureter invasion was observed in $1 \%$ of them. Adrenal was present and positive in just $7 \%$ of the cases. The presence of necrosis was observed in $70 \%$ of the cases, and the sarcomatoid dedifferentiation, in $10 \%$. Lymphadenectomy occurred in $30 \%$ of the performed nephrectomies. Among them, only $5 \%$ were positive. In about $80 \%$ of the cases peritumoral lymphocytic infiltrate was present, in general classified as focal (Table 1).
TABLE 1 - General anatomopathological aspects of 98 cases of renal cell carcinoma submitted to nephrectomy at Hospital Santa Casa de Porto Alegre during 2006-2009

\begin{tabular}{|c|c|c|}
\hline Variable & $\begin{array}{c}\text { Variable } \\
\text { characterization }\end{array}$ & $\begin{array}{l}\text { Cases } \\
(\%)\end{array}$ \\
\hline \multirow{3}{*}{ Laterality } & Right & $50(51)$ \\
\hline & Left & $38(38.8)$ \\
\hline & NR & $10(10.2)$ \\
\hline \multirow{4}{*}{ Tumor size } & pTla & $29(29.6)$ \\
\hline & pT1b & $27(27)$ \\
\hline & pT2a & $26(26.5)$ \\
\hline & pT2b & $16(16.3)$ \\
\hline \multirow{2}{*}{ Histologic type } & Clear cell & $86(87.8)$ \\
\hline & Papillary & $12(12.2)$ \\
\hline \multirow{2}{*}{ Sarcomatoid dedifferentiation } & Present & $10(10.2)$ \\
\hline & Absent & $88(89.8)$ \\
\hline \multirow{4}{*}{ Fuhrman nuclear grade } & 1 & $6(6.1)$ \\
\hline & 2 & $51(52)$ \\
\hline & 3 & $40(40.8)$ \\
\hline & 4 & $1(1)$ \\
\hline \multirow{2}{*}{ Coagulative necrosis } & Present & $70(71.4)$ \\
\hline & Absent & 28 (28.6) \\
\hline \multirow{2}{*}{ Invasion of renal capsule } & Present & $48(49)$ \\
\hline & Absent & $50(51)$ \\
\hline \multirow{2}{*}{ Renal sinus fat invasion } & Present & $10(10.2)$ \\
\hline & Absent & $88(89.8)$ \\
\hline \multirow{2}{*}{ Invasion of hilar vessels } & Present & $8(8.2)$ \\
\hline & Absent & $90(91.8)$ \\
\hline \multirow{2}{*}{ Invasion of renal pelvis } & Present & $23(23.5)$ \\
\hline & Absent & $75(76.5)$ \\
\hline \multirow{2}{*}{ Ureter invasion } & Present & $1(1)$ \\
\hline & Absent & 97 (99) \\
\hline \multirow{2}{*}{ Invasão do adiposo perirrenal } & Present & $24(24.5)$ \\
\hline & Absent & $74(75.5)$ \\
\hline \multirow{5}{*}{ Perirenal adipose tissue invasion } & Present & $79(80.6)$ \\
\hline & Focal & $43(43.9)$ \\
\hline & Moderate & $28(28.6)$ \\
\hline & Intense & $8(8.2)$ \\
\hline & Absent & $19(19.4)$ \\
\hline \multirow{3}{*}{ Lymph nodes } & Positive & $5(5.1)$ \\
\hline & Negative & $22(22.4)$ \\
\hline & NR & $71(73.5)$ \\
\hline \multirow{4}{*}{ Adrenal } & Present & $32(39.8)$ \\
\hline & Positive & $7(21.8)$ \\
\hline & Negative & $25(78.2)$ \\
\hline & NR & $59(60.2)$ \\
\hline
\end{tabular}

pT1a: less than or equal to $4 \mathrm{~cm}$; PT1b: greater than $4 \mathrm{~cm}$ and less than or equal to $7 \mathrm{~cm}$; pT2a: greater than $7 \mathrm{~cm}$ and less than or equal to $10 \mathrm{~cm}$; pT2b: greater than $10 \mathrm{~cm}$; NR: not reported.

In the IHC results, 38 positive $(38.8 \%)$ and 60 negative (61.2\%) cases were obtained for B7-H1, while for survivin 50 positive and 48 negative cases were found. For survivin, cases 
were selected in intervals by staining intensity, being classified by the number of survivin-positive cells. In the analysis of survivinpositive cases by staining intensity, no interval showed any relevance. When analyzing IHC results by the formed groups, we had group 1 with $23 \%$ of the cases, group 2 with $43 \%$, and group 3 with $34 \%$. In group 2 analysis, we found $15 \%$ of positive cases only to B7-H1, and $28 \%$ only to survivin. We found no association between traditional prognostic factors and the expression of the new markers. The exception was the association found between group 1 and the presence of necrosis, which was significant $(\phi<0.0001)$. In the other studied items, variables proved independent ( $\phi$ with no statistical significance) (Table 2).

TABLE 2 - Traditional prognostic factors identified at anatomopathological examination and their correlation with the three groups formed according to the immunohistochemical expression of survivin and B7-H1 in a sample of 98 cases of renal cell carcinoma, using the chi-square test

\begin{tabular}{llc}
\hline \multicolumn{1}{c}{ Variable } & B7-H1 and survivin & $P$ \\
\hline \multirow{2}{*}{ Fuhrman nuclear grade } & Group 1 with group 2 & 0.0923 \\
& Group 1 with group 3 & 0.2147 \\
\hline \multirow{2}{*}{ Invasion of renal capsule } & Group 1 with group 3 & 0.7488 \\
& Group 1 with group 3 & 0.4151 \\
\hline \multirow{2}{*}{ Invasion of renal pelvis } & Group 1 with group 2 & 0.0564 \\
& Group 1 with group 3 & 0.0811 \\
\hline \multirow{2}{*}{ Invasion of the adipose } & Group 1 with group 2 & 0.4022 \\
renal sinus & Group 1 with group 3 & 0.2463 \\
\hline \multirow{2}{*}{ Necrosis } & Group 1 with group 2 & 0.4093 \\
& Group 1 with group 3 & $0.0001^{*}$ \\
\hline
\end{tabular}

Group 1: positive for both markers; group 2: positive for one marker and negative for the other; group 3: negative for both markers.

Source: compiled by the authors.

\section{DISCUSSION}

Our results, in general, confirm data on RCC available in literature. Data on RCC are scarce in Brazilian literature. In Brazil, Instituto Nacional do Câncer (INCA) makes information available on the most common types of cancer. Data on RCC are not included among those due to its low prevalence. The number of RCC cases in Brazil was estimated in 1\%-2\% of total cases, while in the world this number may reach $3 \%$ of total malignancies ${ }^{(20,21,26)}$. Great variation is observed in the number of cases between different places, with higher rates in Europe and North America and lower rates in South America and $\mathrm{Asia}^{(7)}$. Our sample had a total of 98 RCC cases in a period of four years, coming from a single region in Brazil. There is great variation among published national data in relation to the studied period, origin and number of cases forming the samples. For example, there is the report of a national series with 230 cases in a period of 15 years from a single region, or still another series of 508 cases in a period of one year, but with data coming from the whole country. Thus, our data may contribute to enhance knowledge about this disease in our country ${ }^{(6,21)}$.

Demographic data obtained in the study present similarity with those of national and international literature, considering the information relevant to prognosis, as tumor size, histologic type and nuclear grade ${ }^{(31)}$.

As to classification by tumor size, we had a balanced division of cases, however with predominance of smaller tumors: $50 \%$ of the cases presented tumors smaller than 7 $\mathrm{cm}$, while in other series these values were around $40 \%{ }^{(17,23)}$. Tumor size is part of the TNM system and is still important for prognosis, because patients with larger tumors have shorter survival than those who present smaller tumors, with rates ranging from $0 \%$ to $84 \%{ }^{(15)}$.

When RCCs were classified by TNM, there was a concentration in T1 and T2 (73\%). Nardi et al. found 62\% for the same stages, highlighting that among the 508 cases of the sample, 86 were not classified ${ }^{(21)}$. In international series, tumors classified as T1 and T2 are $60 \%-70 \%$ of the cases ${ }^{(11)}$. Literature data show that survival, both in short and long term, is markedly higher for initial tumors (pT1a and pT1b) than for the more advanced ones, reassuring the importance of tumor size for the prognosis of $\mathrm{RCC}^{(6)}$.

The cell carcinoma was the most frequent histological type, followed by the papillary, as one may observe in literature, which estimates $70 \%-80 \%$ for the former and 5\%$15 \%$ for the latter ${ }^{(26,33)}$.

When considering the Fuhrman nuclear grade, we had 93\% of the cases in grades 2 and 3 , whereas in international data this finding reaches $80 \%$, and in the national, around $75 \%(17,21)$.

The presence of necrosis was reported in about $70 \%$ of our cases. In another Brazilian series, this finding was 50\%, while in international data it is around $40 \%$. Along with traditional prognostic factors, this finding has been investigated, because necrosis seems to be a good aggressiveness indicator. So far results are still heterogeneous, but there are studies reinforcing this idea ${ }^{(17,23,26)}$.

In spite of the observed advances in diagnosis, one of the striking RCC characteristics is still its high mortality rates, since survival has remained unaltered in the latest years. It is known that traditional prognostic factors cannot adequately select the most aggressive cases. For this reason, growing interest has been 
observed in literature for the search for new prognostic markers that may be more effective in the selection of more adverse behavior cases. The highlights are those that may help in the selection of cases that would benefit from specific treatments, such as target cell therapy. In the latest years, several studies have been carried out with new promising markers, like survivin and B7-H1, through IHC analysis. In 2005, a study on the genetic profile of RCC demonstrated that survivin was a good marker of tumor aggressiveness, and its expression was related to survival ${ }^{(22)}$. Then, a study at the Mayo Clinic with 312 RCC found 31.1\% of the cases expressing high levels of surviving, and confirmed that those patients had shorter survival and higher risk of death by cancer ${ }^{(25,32)}$. In 2010, the association between the marker and other pathological factors was studied, and it was observed that staging and tumor grade, as well as lymph node involvement, were significantly associated with its expression levels. So, survivin was considered an independent prognostic factor for $\mathrm{RCC}^{(16)}$.

In 2004 the B7-H1 study began, in a series of 196 cases of RCC, with fresh frozen tissue. The membrane positive staining was used for analysis of the expression, with a cut-off of $10 \%$ cells and conventional microscopy analysis made by a pathologist. In this study, positivity was found to be $37.2 \%$. It was observed that the expression of this marker in primary RCCs was associated with shorter survival ${ }^{(30)}$. In this work, as well as in others by the same group, the primary antibody 5HI (B7-H1 anti-human monoclonal antibody), developed in that institution, was utilized ${ }^{(8)}$. In 2005, a new study on the marker, now in metastatic tumors, confirms the same finding. In that research, samples of frozen fresh tissue were still used. The membrane staining and the cut-off point of 5\%$10 \%$ for positive cases were considered, still using the conventional microscopy analysis by a pathologist. This group encompassed 130 cases, and positivity was found in $66.3 \%{ }^{(29)}$. The same authors performed a study in 2006, using paraffin-embedded material and maintaining all the other previous parameters. The series had 306 cases, and obtained positivity of $24 \%$. It was also described that the positive expression of this marker in RCC subtype clear cell was associated with adverse pathological findings, such as advanced stage, larger tumor size, high nuclear grade and necrosis. Besides, the relationship between positivity to the marker and increased risk of cancer progression and death was observed, emphasizing the hypothesis that this may be a marker of poor prognosis in $\mathrm{RCC}^{(28)}$.

After the promising results of the isolated analyses, the study of combined expression of RCC markers was initiated. In 298 cases, double expression was seen in $20 \%$ of them and its association with poor prognostic was noted, so that it could be considered a predictor of tumor aggressiveness. The cut-off for survivin analysis was $2 \%$, and for $\mathrm{B} 7-\mathrm{H1}, 5 \%$. The microscopy analysis was digital, and the used values were defined in a previous study ${ }^{(25)}$. In 2009, a new study describes the development of a biomarker-based nomogram, called BioScore, which uses characteristics related to the combined expression of survivin, B7-H1 and Ki-67. That study analyzed 643 cases and tested whether expressions in combination would improve the predictive capacity of markers, previously observed in individual analyses. The parameters considered for analysis of B7-H1 expression were: membrane staining and cut-off point of 5\%-10\% stained cells. For survivin, nuclear staining was considered, a semiquantitative analysis obtained the number of cells per $\mathrm{mm}^{2}$, resulting in high or low survivin. The analysis of the expression was determined by a pathologist using conventional microscopy. A total of $15.3 \%$ positive cases were obtained for B7$\mathrm{H1}$ and $31.2 \%$ for high survivin ${ }^{(24)}$. In our study we analyzed both markers isolated and in combination. We had isolated positivity of $38.8 \%$ for $\mathrm{B} 7-\mathrm{H1}$, whereas in literature we find positivity results with great variation, with rates of $24 \%-66 \%{ }^{(14,28,30)}$. In the isolated analysis of survivin we had around $50 \%$ of positive cases, while in other studies these values ranged from $30 \%$ to $32 \%{ }^{(14,24)}$. Regarding the analysis of markers in combination, we obtained $23 \%$ positivity, when in literature this result was $13.8 \%{ }^{(14)}$. It is important to say that even following the descriptive methodology, we found it difficult to work with antibodies ${ }^{(24)}$. Perhaps one of our limitations is the fact that we used the commercially available antibody, when the other group used an antibody of their own ${ }^{(28,29,30)}$.

After the IHC study we formed groups - 1,2, and 3-, considering the result of expression for both markers. By investigating the relationship between groups and pathological data, we found no association between group and histologic type. Even with the numerical limitation of our sample, we obtained this new piece of information in literature. The only obtained association between pathological data and the expression of markers was that found between necrosis and group 1 (positive cases for both markers), presenting statistical significance.

An enlargement of data on necrosis in RCC has been lately noted in literature. In an extensive RCC case study on mixed series, positivity was found in $28 \%$. Besides, association with high level tumors, advanced stages, higher chance of lymph node involvement, and distance metastasis was reported. Thereby, necrosis was considered an independent factor for survival in $\mathrm{RCC}^{(27)}$. In a new study, modifications were suggested in necrosis analysis. The author suggested that microscopic assessment of necrosis should be more detailed, instead of just reporting its presence or absence. With this in mind, the creation of a score for necrosis was proposed. This study found necrosis in $66 \%$ of the cases and concluded that even if it had not behaved as an independent factor, its presence is a factor of poor prognosis, being associated with adverse factors, like TNM staging, high nuclear grade, 
vascular invasion and sarcomatoid dedifferentiation. Consequently, the author suggests that the presence of tumor necrosis should be routinely cited in the pathological report of nephrectomies by $\mathrm{RCC}^{(12)}$. There is also an account of the association between histologic type and necrosis, with effects on prognosis, being more important in the type clear cells than in the others ${ }^{(7)}$.

There are also controversial data in literature on the subject. In a series of 213 cases, necrosis was mentioned in $63.8 \%$, but necrosis presence or extension was not proved to be relevant for prognosis ${ }^{(19)}$. In a study of 1,526 patients, tumor necrosis was encountered in $31.2 \%$. Besides that, it was demonstrated that it was important for mortality, but it was not an independent prognostic factor for survival ${ }^{(10)}$. However, in the work that described the creation of a prognostic nomogram for RCC at the Mayo Clinic, necrosis was incorporated as a factor to be assessed ${ }^{(9)}$. Thus, our data seem to add to those that point necrosis as important for RCC prognosis, and as such, it seems to us that its assessment should be part of the pathological record.

\section{CONCLUSION}

Considering the discussed data, we believe that the studied markers are promising, but further research is still necessary, with more easily replicable methods. In our opinion, nowadays, data still seem heterogeneous.

In the study of the relationships between pathological data and the expression of markers B7-H1 and survivin, association between histologic type and their expression was not found. We obtained, however, a significant association of combined positivity of markers and necrosis, reinforcing the importance of this factor. Necrosis should be assessed more carefully in the microscopy study, becoming a routine in RCC records.

In the current scenario, studies that search to find markers for selection of more aggressive cases of RCC are still necessary and go on having an important role for the improvement of the disease prognosis.

\section{RESUMO}

Introdução: O carcinoma de células renais (CCR) é uma doença de comportamento agressivo em todo o mundo. Objetivo: Estudar os fatores prognósticos tradicionais identificados no exame anatomopatológico e sua correlação com a expressão imunoistoquímica dos novos marcadores survivina e B7-H1. Materiais e métodos: Em um hospital de referência de Porto Alegre, foi realizado um estudo transversal de CCR, com pacientes que realizaram nefrectomia total, no periodo de 2006 a 2009. Foram selecionados aqueles com os tipos histológicos mais comuns: células claras epapilares. Fatores prognósticos tradicionais foram obtidos por meio da revisão de dados patológicos relevantes dos casos, como tamanho, necrose, tipo bistológico, grau nuclear e sistema tumor-linfonodo-metástase (TNM). Também se realizou estudo imunoistoquímico (IMQ) da amostra, com o uso dos marcadores survivina e B7-H1. Resultados: Obtivemos 98 casos, com 90\% deles do tipo células claras, 73\% classificados como T1 e T2, a maioria com grau nuclear de Fubrman 2 e 3 e cerca de $70 \%$ da amostra positivos para necrose. Já no estudo IMQ foi encontrada positividade em 38 casos para o B7-H1 e em 50 para survivina. Ao considerarmos a associação entre os fatores prognósticos tradicionais e a expressão dos marcadores, encontramos associação somente entre o grupo positivo para os marcadores e necrose $(p<0,001)$. Conclusão: Tal achado vai ao encontro dos dados da literatura que vêm realçando a importância da necrose no prognóstico dos CCR.

Unitermos: carcinoma renal; marcadores tumorais; B7-H1; survivina; imunoistoquímica; fatores prognósticos.

\section{REFERENCES}

1. ADIDA, C. et al. Developmentally regulated expression of the novel cancer anti-apoptosis gene survivin in human and mouse differentiation. Am J Pathol, v. 152, n. 1, p. 43-49, 1998.

2. ANDERSEN, M. H. et al. The universal character of the tumor-associated antigen survivin. Clin Cancer Res, v. 15, n. 13, p. 5991-4, 2007.
3. ATKINS, M. B. et al. Innovations and challenges in renal cell carcinoma: summary statement from the Second Cambridge Conference. Clin Cancer Res, v. 15, n. 13, p. 667-670, 2007.

4. CHANG, Y. H. et al. Prognostic value of TNM stage and tumor necrosis for renal cell carcinoma. Kaobsiung J Med Sci, v. 27,n. 2, p. 59-63, 2011.

5. CHOW, W. H.; DONG, L. M.; DEVESA, S. S. Epidemiology and risk factors for kidney cancer. Nat Rev Urol, v. 7, n. 5, p. 245-57, 2010. 
6. DALL'OGLIO, M. F. et al. Impact of clinicopathological parameters in patients treated for renal cell carcinoma. J Urol, v. 177, n. 5, p. 1687-91, 2007.

7. DELAHUNT, B.; NACEY, J. N. Renal cell carcinoma. II. Histological indicators of prognosis. Pathology, v. 19,n. 3, p. 25-8, 1987.

8. DONG, H. et al. B7-H1, a third member of the B7 family, co-stimulates T-cell proliferation and interleukin-10 secretion. Nat Med, v. 5, n. 12, p.1365-1369, 1999.

9. FRANK, I. et al. An outcome prediction model for patients with clear cell renal cell carcinoma treated with radical nephrectomy based on tumor stage, size, grade and necrosis: the SSIGN score.J Urol, v. 168, n. 6 , p. 2395-400, 2002.

10. ISBARN, H. et al. Limited prognostic value of tumor necrosis in patients with renal cell carcinoma. Urology, v. 75, n. 6, p.1378-84, 2010.

11. KARAKIEWICZ, P. I. et al. Conditional survival predictions after nephrectomy for renal cell carcinoma. J Urol, v. 182, n. 6, p. 2607-12, 2009.

12. KLATTE, T. et al. Presence of tumor necrosis is not a significant predictor of survival in clear cell renal cell carcinoma: higher prognostic accuracy of extent based rather than presence/absence classification. JUrol, v. 181, n. 4, p. 1558-64, 2009.

13. KOSARI, F. et al. Clear cell renal cell carcinoma: gene expression analyses identify a potential signature for tumor aggressiveness. Clin Cancer Res, v. 11, n. 14, p. 5128-39, 2005.

14. KRAMBECK, A. E. et al. Survivin and B7-H1 are collaborative predictors of survival and represent potential therapeutic targets for patients with renal cell carcinoma. Clin Cancer Res, v.13, n. 6, p.1749-1756, 2007.

15. LAM, J. S. et al. Prognostic factors and selection for clinical studies of patients with kidney cancer. Crit Rev Oncol Hematol, v. 65, n. 3, p. 235-62, 2008.

16. LEI, Y. et al. Prognostic significance of survivin expression in renal cell cancer and its correlation with radioresistance. Mol Cell Biochem, v. 344, n. 1-2, p. 23-31, 2010.

17. LEIBOVICH, B. C. et al. Histological subtype is an independent predictor of outcome for patients with renal cell carcinoma. J Urol, v. 183, n. 4, p.1309-1316, 2010.

18. LI, F. Role of survivin and its splice variants in tumorigenesis. $\mathrm{Br} \mathrm{J}$ Cancer, v. 92, n. 2, p. 212-6, 2005.

19. MINERVINI, A. et al. Prognostic role of histological necrosis for nonmetastatic clear cell renal cell carcinoma: correlation with pathological features and molecular markers. J Urol, v.180, n. 4, p. 1284-9, 2008.
20. NAITO, S. et al. Kidney Cancer Working Group report. Jpn J Clin Oncol, v. 40, Suppl 1, p. 51-56, 2010.

21. NARDI, A. C. et al. Epidemiologic characteristics of renal cell carcinoma in Brazil. Int Braz J Urol, v. 36, n. 2, p. 151-58, 2010.

22. NATIONAL CANCER INSTITUTE - U. S. National Institutes of Health. Available at: http://www.cancer.gov/cancertopics/types/kidney. Accessed on: Feb 2013.

23. ORNELLAS, A. A. et al. Prognostic factors in renal cell carcinoma: analysis of 227 patients treated at the Brazilian National Cancer Institute. Int Braz J Urol, v. 38, n. 2, p. 185-94, 2012.

24. PARKER, A. S. et al. Development and evaluation of BioScore: a biomarker panel to enhance prognostic algorithms for clear cell renal cell carcinoma. Cancer, v. 15, n. 115, p. 2092-103, 2009.

25. PARKER, A. S. et al. High expression levels of survivin protein are an independent predictor of poor outcome among patients treated surgically for clear cell renal cell carcinoma. Cancer, v. 107, p. 37-45, 2006.

26. RINI, B. I.; CAMPBELL, S. C.; ESCUDIER, B. Renal cell carcinoma. Lancet, v. 28, n. 373(9669), p. 1119-32, 2009.

27. SENGUPTA, S. et al. Histologic coagulative tumor necrosis as a prognostic indicator of renal cell carcinoma aggressiveness. Cancer, v. 104, n. 3, p. 511-20, 2005.

28. THOMPSON, R. H. et al. Significance of B7-H1 overexpression in kidney cancer. Clin Genitourin Cancer, v. 5, n. 3, p. 206-11, 2006.

29. THOMPSON, R. H. et al. Costimulatory molecule B7-H1 in primary and metastatic clear cell renal cell carcinoma. Cancer, v. 104, n. 10, p. 2084-2089, 2005.

30. THOMPSON, R. H. et al. Costimulatory B7-H1 in renal cell carcinoma patients: indicator of tumor aggressiveness and potential therapeutic target. Proc Nat Acad Sci USA, v. 101, n. 49, p. 17174-17179, 2004

31. VOLPE, A.; PATARD, J. J. Prognostic factors in renal cell carcinoma. World J Urol, v. 28, n. 3, p. 319-327, 2010.

32. WANG, G. C. et al. Expression of cortactin and survivin in renal cell carcinoma associated with tumor aggressiveness. World J Urol, v. 27, n. 4, p. 557-563, 2009.

33. YAMASHITA, S. et al. Morphological subtyping of papillary renal cell carcinoma: clinicopathological characteristics and prognosis. Int J Urol, v. 14, n. 8, p. 679-83, 2007.

34. ZHAO, J. et al. The ubiquitin-proteasome pathway regulates survivin degradation in a cell cycle-dependent manner. J Cell Sci, v. 113, n. 23, p. 4363-71, 2000 .

\section{MAILING ADDRESS}

\section{Alexandra M. S. de Freitas}

Universidade Federal de Ciências da Saúde de Porto Alegre (UFCSPA); Rua Sarmento Leite, 245; CEP: 90050-170; Porto Alegre-RS; Brazil.; e-mail: amsfreitas@ hotmail.com. 